\title{
Juvenile Criminality in Kosovo
}

\author{
Professor Azem Hajdari \\ Faculty of Law, University of Prishtina "Hasan Prishtina" \\ Pristina, Kosovo \\ E-mail: azemhajdari@ outlook.com
}

Received: December 9, 2014 Accepted: December 24, 2014 Published: March 26, 2015

doi:10.5296/iss.v3i1.7326 URL: http//dx.doi.org/10.5296/iss.v3i1.7326

\begin{abstract}
Juvenile criminality presents a complicated criminal phenomenon for studying. This criminality, in global extent, in the recent decades has achieved a relatively high participation in terms of general criminality. Such participation, observed in the modest results of this scientific paper, it is noticed to be present also in Kosovo. A characteristic of juvenile criminality is that nowadays minors are committing all types of criminal offences. Regardless of this, this perpetrator's category especially is focused in commission of criminal offences against property and criminal offences against life and body. In fact juvenile perpetrators of criminal offences are achieving a relatively high degree of participation also in criminality against road traffic safety, criminality in the narcotic field, but also in other types of criminal offences. The consecuences caused by juvenile criminality are numerous and diverse. Its causes are numerous and of different types. These causes in most of the cases are identic to those of general criminality, but also specific related exclusively with minors. Within this article are elaborated these components, including measures who guarantee their elimination.
\end{abstract}

Keywords: criminality, juveniles, criminal sanctions, prevention, repression 
1. Introduction

Kosovo as many world countries in its developing path is facing a lot of challenges. One of them has to deal with juvenile criminality phenomenon, including its prevention and fighting. Kosovo for several decades faced growing trend of criminality in general and juvenile criminality in particular. Also during the period of time 2009-2013 included in this research is noticed a very relatively high degree presence of juvenile phenomenon criminality. Criminal offences againt property, life and body etc committed by minors have become common ocurrences causing dissatisfaction among citizens. This dissatisfaction is manifested especially due to the fact that society is not sufficiently capable to prevent this criminal phenomenon respectively to remove this category of perpetrators from crime. In this regard, through this scientific paper is made a modest attempt in order to increase the awareness of competent bodies and Kosovo society in general for a more serious engagement towards prevention and combating this criminal phenomenon.

\section{The Meaning of Juvenile Criminality}

The definition of juvenile criminality is a complicated issue. This complexity conditions the necessity that this criminality to be treated not only in criminal law terms, but at the same time in sociological and psychological adequate treatement. On this course, defining juvenile criminality means elaborating criminological, sociological, political-criminal, criminal-law, psychlogical, aspects as well as other aspects of this problematic (Note 1).

The issue of juvenile criminality definiton complicates even more the problem's distinction that still exists between linguistic meaning and the content of the concept and the essence of this phenomenon. The influence here is manifested also through practice, or better to say non-practice of usage of this term in state bodies work and daily life (Note 2).

It should be emphasized the fact that the definition of juvenile criminality complicates more also different forms of organized criminal juvenile groups. Here it is about especially in the phenomenon of their participation together with adults in political and terrorism activities, repeatition of crimes etc. (Note 3).

These and other factors had an impact regarding the content of juvenile criminality to exist diverse point of views. Despite the existing views, prevails the opinion that by juvenile criminality is implied illegal behaviours of minors (Note 4).

\section{The Position of Minors Under Kosovo Criminal Legislation}

Criminal legal matters related to juveniles are addressed through Criminal Code (Note 5) and in particular Juvenile Justice Code (Note 6). Regarding the Criminal Code I evaluate important to be elaborated only one legal provision which among others is referred also to juveniles. This provision deals with criminal liability. The article 17 paragraph 3 of this Code determines that a person is not criminally liable if, at the time of the commission of a criminal offence, he or she is under the age of fourteen (14) years. This paragraph means that for the committed offence, under the conditions determined by this Code, shall be deemed criminally liable the person who has reached the age of fourteen years. Therefore, 


\section{Macrothink

this provison regulates also the issue of juvenile criminal liability (14-18 years), but without entering in further details of regulating this issue. As it turns out, in substance the issue of minors treatment is regulated through Juvenile Justice Code.

The juvenile treatement addressed through Juvenile Justice Code (Note 7) is manifested in criminal material aspect as well as in criminal procedural and in the execution of criminal sanctions aspects. In criminal material aspect the special minors treatement in comparison to the adult perpetrators of criminal offences is expressed through prediction in this Code of diversity measures and an advanced number of measures and alternative sanctions against this category of criminal offences perpetrators.

Criminal material juvenile treatement consists in the fact that is excluded the criminal liablity of perpetrators regarding this category of criminal offences. Thus, for all young juveniles (14-16 years) the criminal liability is excluded absolutely because against them may be imposed only diversity and educational measures. In meanwhile, the punishment of imprisonment for juveniles is foresenn only exceptionally and only if it comes to adult juveniles (16-18 years) and who has committed a criminal offence for which is foreseen the punishment of imprisonment of over five years and in cases when imposition of the educational measure would not be adequate due to the seriousness of the criminal offence, its consequences and the level of liability (Note 8). Finally, criminal material treatment of juveniles is manifested also through giving broad authorizations to criminal justice bodies (prosecutions and courts) in giving up from prosecution and selecting measures and punishments that shall be imposed to juveniles as well as in prediction of special jurisprudence bodies aimed combating juveniles criminality for example judges for juveniles (Note 9).

In criminal-procedural terms the special treatment of minors in comparison to adult perpetrators is manifested through prohibition of possibility of adjudicating juvenile in the absence, the prediction of the possibility of parent and guardianship authority participation in proceedings when minors are adjudicated; addressing mandatory defence in all cases when the minor is adjudicated; the lack of main trial publicity; the establishment of solutions addressing urgent action of criminal procedure bodies and determination of the obligation to testify of every person having knowledge concerning the circumstances deemed necessary in order to ascertain psychological development of juvenile, recognition of its personality and the conditions under which he lives (Note 10).

In meanwhile, in terms of criminal sanctions execution against minors their special treatment in comparison to adults perpertrators of criminal offence is expressed through forecasting their re-education and re-socialization special programs. They should be enabled education, professional preparation similar as their elderly who are in freedom; the adjustment of educational measure related to application measure dedicated to the minor, by respecting their personality and encouraging their physical, moral and intelectual development as well as by defending their physical and mental health (Note 11).

\section{Some Data Conceming Juveniles Criminality in General in Kosovo}


Empirical data prove that juveniles criminality especially in the last two decades is growing. This growth is particularly noticeable in countries with high economic development. The percentage of juveniles participation in the total number of criminal offences perpetrators, depending on the country ranges from $5-15 \%$ (Note 12). In some countries this juvenile participation in terms of general criminality reaches $30 \%$. It is considered that this is the case in France, Germany, USA etc. (Note 13). A higher level of juvenile participation in general criminality is recorded in crimes against property, crimes of violence, illicit drug trafficking and prostitution phenomenon. Published data prove also for growing phenomenon of juveniles organization in minors gangs, in the commission of serious crimes, political terrorism etc. (Note 14).

A relatively high level of juveniles participation in the commission of criminal offences continues to be also in Kosovo. According to the data made public juveniles during the period of time 2009-2013 have reached participation in general criminality around $7 \%$.

In the following table will be presented the number of juveniles against whom were imposed criminal sanctions and their relation against perpetrators generally convicted for the commission of criminal offences during the period of time 2009-2013.

Table 1. The data on juveniles against whom were imposed criminal sanctions and perpetrators generally convicted

\begin{tabular}{|c|c|c|}
\hline $\begin{array}{l}\text { Period o } \\
\text { time }\end{array}$ & $\begin{array}{l}\text { The number of juveniles against whom were imposed } \\
\text { criminal sanctions for commission of criminal } \\
\text { offences }\end{array}$ & $\begin{array}{l}\text { The total number of } \\
\text { persons convicted }\end{array}$ \\
\hline $\begin{array}{l}2009 \\
2013\end{array}$ & $-5238($ Note 15$)$ & 76441 (Note 16) \\
\hline
\end{tabular}

According to these data during the period of time 2009-2013 Kosovo courts imposed criminal sanctions in a total of 5238 juvenile perpetrators of criminal offences or an average punished 1047.6 perpetrators per year. These data indicate that the number of juveniles against whom were imposed criminal sanctions for commission of criminal offences in Kosovo is relatively high, and in total number of perpetrators punished for commission of criminal offences is around $7 \%$.

In the commission of criminal offences by minors during the research period is estimated to have influenced social and political fragile circumstances continuing to accompany the country and the complicated process of Kosovo state creation. Also, here had an impact problems regarding the manner of functioning criminal justice system, uncontrolled and numerous migration movements, the high density of population, poor housing conditions, the low level of economic, social and cultural development, the high level of unemployment, non adequate functioning of institutions entrusted with the education of new generations, the decrease level care of family to this category of persons etc.

\subsection{The Dynamic}




\section{Macrothink $\Lambda$ Institute ${ }^{m}$}

In order to be able to evaluate juveniles criminality movement trend is necessary to reflect the number of juveniles convicted for the commission of criminal offences through years. To reflect the dynamic of juveniles criminality in Kosovo in a particular table will be presented Kosovo Statistical Agency and Kosovo Judicial Council data over the number of juveniles convicted for the commission of criminal offences during the period of time 2009-2013.

Table 2. The juvenile dynamics against whom were imposed criminal sanctions through years

\begin{tabular}{lc}
\hline Years & $\begin{array}{r}\text { The number of juveniles against } \\
\text { for commission of criminal offences }\end{array}$ \\
\hline 2009 & 948 \\
2010 & 670 \\
2011 & 1678 \\
2012 & 1141 \\
2013 & 801 \\
In total & 5238 \\
\hline
\end{tabular}

According to these data Kosovo courts during the period of time 2009-2013 imposed 5238 criminal sanctions (Note 17) against juvenile perpetrators of criminal offences. These data should be taken with great caution. This due to the fact a big number of juvenile perpetrators of criminal offences is never detected, whereas to a number state prosecutor according to legal solutions suspends prosecution. Also there is a considerable number of prosecution cases that have come to statutory limitation etc. As it turns out, during the years 2011 and 2013 juvenile criminality achieved a relative growth trend. The causes of this situation should be sought in the worsening of country economic situation from year to year, the manifestation of numerous problems in matters of functioning educational institutions, the considerably degradation of the justice system and to the family role itself in society etc.

\subsection{Territorial Scope}

Territorial distribution of juveniles criminality has a special importance to the criminalpolicy orientations of its preventing and combating. In this regard, in the following of this scientific paper will be presented the data for juvenile perpetrators of criminal offences against whom were imposed criminal sanctions by Basic Courts during the period of time 2009-2013.

According to these data the highest number of juvenile perpetrators of criminal offences is convicted by Basic Court in Gjilan (2078 cases), after that come Basic Court in Prishtina (1045 cases), Basic Court in Prizren (866 cases), and then Basic Court in Gjakova (490 cases), Basic Court in Ferizaj (387 cases), and Basic Court in Peja (322 cases) (Note 19). 
Table 3. Territorial scope of juveniles criminality

\begin{tabular}{lc}
\hline Courts & $\begin{array}{c}\text { The number of juveniles against whom } \\
\text { were imposed criminal }\end{array}$ \\
\hline Basic Court in Gjilan & 2078 \\
Basic Court in Prishtina & 1045 \\
Basic Court in Mitrovica & 50 (Note 18$)$ \\
Basic Court in Peja & 322 \\
Basic Court in Gjakova & 490 \\
Basic Court in Prizren & 866 \\
Basic Court in Ferizaj & 387 \\
In total & 5238 \\
\hline
\end{tabular}

Modest results of this scientific paper indicate that juvenile criminality mostly is spreaded in cities, whereas in rural areas is less present. This situation apart from greatly abandoment of rural areas characterized Kosovo post-war developments (1999) is dictated also by the fact that Kosovo cities, for many reasons, have become centers attracting criminal offences perpetrators in undertaking their criminal activities.

This discrepancy of Kosovo juvenile criminality is conditioned, first of all, due to the fact that in Gjilan, Prishtina and Prizren municipalities criminal factors of this criminal phenomenon is appeared to be significantlly more accentuated than in other municipalities. Here in particular is noticeable the impact of poverty problem, unemployment, uncontrolled and large migration of population, demographic situation, poor housing conditions and other problems concerning the situation in schools, family, appropriate spaces to exercise asocial activities (wandering, begging, prostitution etc.). Another factor which according to my opinion has had a major impact on the appearance of juvenile criminality during the period of time 2009-2013 is also the fragile security situation and slow functioning of bodies who establishe the criminal justice system in the country (Note 20).

\section{Some of the Manifestation Forms of Juvenile Criminality}

There are numerous and diverse actions by which juveniles commit criminal offences. Moreover, in legal literature is emphasized that these actions almost entirely correspond with adults criminal actions. In the following of this article, respectively in the following table, will be presented the data over the number of juvenile perpetrators against whom were imposed criminal sanctions, observed this in the context of criminal offences types committed by this category of perpetrators during the period of time 2009-2013. 
Table 4. The number of juvenile perpetrators against whom were imposed criminal sanctions according to the type of committed criminal offence

\begin{tabular}{lc}
\hline $\begin{array}{l}\text { The type of criminal offences committed by } \\
\text { juvenilies }\end{array}$ & $\begin{array}{c}\text { The number of juveniles against } \\
\text { whom were imposed criminal } \\
\text { sanctions }\end{array}$ \\
\hline 1.Criminal offences against life and body \\
1.1.Light body injury & 478 \\
1.2. Grievous body injury & 354 \\
1.3.Participation in a brawl & 266 \\
1.4.Murder & 7 \\
1.5.Other criminal offences against life and body & 23 \\
In total criminal offences against life and body & 1128 \\
2.Criminal offences against property & \\
2.1.Theft & 772 \\
2.2.Aggravated theft & 454 \\
2.3.Other criminal offences against property & 215 \\
Total criminal offences against property & 1441 \\
3. Other criminal offences & 111 \\
3.1.Forest theft & 213 \\
3.2.Endangering public traffic & 121 \\
3.3.Trafficking of narcotics & 2214 \\
3.4.Other criminal offences & 5238 \\
In total & \\
\hline
\end{tabular}

These data prove that juveniles during the period of time 2009-2013 mostly have committed criminal offences against property (in 1441 cases) then the criminal offences against life and body (in 1128 cases), endangering public traffic (in 213 cases), trafficking of narcotics (in 121 cases), forest theft (in 111 cases) and other types of criminal offences (in 2214 cases). The results of this scientific paper indicate that juveniles during the research period in Kosovo had committed different types of criminal offences, dominating those against property and life and body (Note 21).

Conducted researches prove that juvenile perpatrators of criminal offences mostly were from problematic families, with many members and by the absence of parents. This research also indicates that juveniles had committed criminal offences in different places (markets, schools, shops etc.), for different motives (jealousy, material interest etc., depending on the type of committed criminal offence) (Note 22) and in 56\% of cases within criminal cooperation. This situation conditions the need that society should do more and more in terms of preventing juveniles criminality, especially through advancing the family role, the level of education at schools, increasing the justice system functioning level, especially to police, state prosecution and courts; raising the level of economic development etc.

6 .Some Personal Data of Juvenile Perpetrators of Criminal Offences 
A comprehensive study of juvenile criminality requires beside others also the detection of some personal and social characteristics of juvenile perpetrators of criminal offences. Consequently in order to study issues concerning personal characteristics of juvenile perpetrators of criminal offences, as important components in explaining this form of criminality we used the data of juvenile perpetrators of criminal offences that we studied. In this regard, it will be discussed about the age, gender, educational level and perpetrator's social affiliation.

\subsection{Gender}

A numerous statistical data from judicial practice as well as the data of criminological researches prove that the perpetrators of criminal offences belong to persons of different ages. This fact is evident in all types of criminal offences. The results of this scientific paper prove that in this regard there are no distinctions concerning juvenile perpetrators criminal offences category. On this course, in terms of age, there is approximately a similar appearance of two categories of minors (young juveniles and adult juveniles), with a relatively small dominance degree of young juveniles.

In the following table will be presented the juvenile's age against whom were imposed criminal sanctions for the commission of criminal offences in Kosovo during the period of time 2009-2013.

Table 5. The age of juveniles perpetrators against whom were imposed criminal sanctions

\begin{tabular}{lc}
\hline Age & $\begin{array}{c}\text { The number of juveniles against whom were imposed } \\
\text { criminal sanctions for the commission of criminal } \\
\text { offences }\end{array}$ \\
$14-16$ & 2812 \\
$16-18$ & 1226 \\
In total & 5238 \\
\hline
\end{tabular}

The higher percentage of young juvenile participation in the total number of committed criminal offences by minors is explained by the accelerated bio - psychic development of youth in modern times, and other specifics characterizing nowadays persons aged $14-16$ years (Note 23). In this way to such minors is noticeable a gradual growth trend of negative attitude against family, school and social environment generally. These persons like to have uncontrolled life, out of restrictions that impose legal norms. It is considered that this situation, of course is linked with the puberty issue, which as is known presents a very complex phase in the development of minor's personality. In this regard is deemed very necessary to pay a special attention to the children of this age, especially in terms of education development, school attendance, their behavior in social environment etc. 
Exists a general impression that criminality is a typical phenomenon of masculine gender. "Criminological researches conducted in many world countries prove that among criminal offences perpetrators dominate persons of masculine gender (Note 24)." This fact is proven also by modest results of this scientific paper. In this regard, the data used prove that as a subject of these criminal offences appear mainly males.

In the following table will be reflected the gender of minors against whom were imposed criminal sanctions for commission of criminal offences in Kosovo during the period of time 2009-2013.

Table 6. The gender of juvenile perpetrators against whom were imposed criminal sanctions

\begin{tabular}{lc}
\hline Gender & \multicolumn{2}{c}{ The number of minors against whom were imposed } \\
& criminal sanctions for the commission of criminal offences \\
\hline Male & 4813 \\
Female & 425 \\
In total & 5238 \\
\hline
\end{tabular}

According to these data minors from masculine gender participate in general juvenile criminality with $91.88 \%$, whereas females participate only with $8.12 \%$ (Note 25 ).

The issue of poor female participation in criminal activities which some authors link with sensitivity and physical disabilities is unlikely to be present in the issue related to juveniles criminality phenomenon. This is due to the fact that female minors usually develop quickly and pass puberty stage sooner than males. This means that they biologically in terms of the age, are in a more favorable situation to deal with criminality.

It is deemed that in Kosovo reality, the fact of very low participation of females in the commission of criminal offences in comparison to males must be linked with the so called "special care" made to persons of feminine gender from family. Unlike this, masculine gender minors are not monitored sufficiently (are more free in terms of conducting different activities) in accompaniment with their peers. In this excessive freedom they face situations allowing easier infection by the so called "problematic places" and thus they commit different criminal offences.

\subsection{Perpetrator's Educational Level}

Numerous criminological researches consider education as an important factor in prevention of criminality. This fact is proven also by modest results of this paper. What is the participation degree of minors against whom were imposed criminal sanctions for commission of criminal offences during the period of time 2009-2013 based on the perpetrator's educational level is best proved from the data that will be reflected in the following table. 
Table 7. The educational level of minors against whom were imposed criminal sanctions

\begin{tabular}{lc}
\hline $\begin{array}{l}\text { Educational level of minors against whom } \\
\text { were imposed criminal sanctions }\end{array}$ & $\begin{array}{c}\text { The number of minors against whom were } \\
\text { imposed criminal sanctions }\end{array}$ \\
\hline Without a complete primary eduation & 1611 \\
With primary education & 1723 \\
With secondary education & 1904 \\
In total & 5238 \\
\hline
\end{tabular}

According to these data in the commission of minors criminal offences dominate persons without a complete primary education and those with only primary education completed, which together participate in 3334 cases, whereas after them come persons with seco ndary education in 1904 cases (Note 26). The higher degree participation of minors without a complete primary education and those who have completed only primary school level in the commission of criminal offences should be seen in the low level of knowled ge they have for understanding social processes in general including the crime phenomenon (consequences it causes), but without excluding other influential factors, just like can be those linked with the manipulation possibility of these persons by differe nt problematic persons etc.

\subsection{Social Affiliation}

Numerous data from judicial practice and the researches from criminological studies attest that the biggest number of perpetrators of criminal offences is from unemployed people and those who have difficult material situation. This fact has been proven also by modest results of this paper.

In the following table will be presented the data over social affiliation of minors against whom were imposed criminal sanctions for the commission of criminal offences d uring the period of time 2009-2013.

Table 8. Social affiliation of minors against whom were imposed criminal sanctions

\begin{tabular}{lc}
\hline $\begin{array}{l}\text { Social affiliation of minors against whom } \\
\text { were imposed criminal sanctions }\end{array}$ & $\begin{array}{c}\text { The number of minors against whom } \\
\text { were imposed criminal sanctions }\end{array}$ \\
Employed & 97 \\
\hline Unemployed & 5141 \\
In total & 5238 \\
\hline
\end{tabular}

According to these data from 5238 minors against whom were imposed criminal sanctions 5141 were unemployed persons. According to the results of this scientific paper around $80 \%$ of minors against whom were imposed criminal sanctions derive from families with poor economic situation. The commission of such high number of criminal offences by unemployed minors is explained by the difficult economic situation of country, many 
Kosovo families and with the lack of citizen's perspective, especially youth concerning their employment. On the basis of this fact it may be concluded that with the growth of perspective and wellbeing of minors it could come to the reduction of cases regarding the commission of criminal offences.

\section{Measures for Combating Juveniles Criminality}

For preventing and combating juvenile criminality during the historical development of human society were used different tools and methods. All the measures used for combating juvenile criminality can be divided into: preventive and repressive measures.

\subsection{Preventive Measures}

By the word preventive measures is understood the entirety of actions undertaken by a wide circle of state entities in order to prevent criminality appearance as sociopathological phenomenon, through eliminating and combating causes and conditions who determine it. (Note 27). Preventive measures undertaken in order to prevent juvenile criminality may be numerous and varied. These measures must be focused on:

- Strengthening and consolidation of democracy and the rule of law;

- Establishing educational and cultural level of population and minors in particular;

- Solving numerous problems which schools face nowadays in Kosovo, including raising academic level of teaching staff, the creation of genuine teaching programs, strengthening the discipline and security at schools, the development through different courses of justice subjects in order to educate new generations with the feeling of respecting laws and rules of the rule of law;

- The inclusiveness of youth at schools and undertaking measures in order to prevent the abandonment school phenomenon by pupils;

- Raising the economy and increasing number of employees especially from poor families, by which derive the majority of delinquents minors;

- The solution of social problems especially to problematic families and to those with many members;

- The evidence of problematic minors by authorized bodies and their calling in conversations and professional counseling in order to inform them for the consequences they may face as a result of criminal actions;

- The increase of criminal justice bodies work, especially courts in resolving minors criminal cases and the adjustment of imposed criminal sanctions to the juvenile perpetrator's personality on purpose their faster re-socialization;

- Work advancement in minors re-socialization process plan within penitentiary institutions and minors post-penal treatment; 


\section{Macrothink Mnstitute ${ }^{\mathrm{m}}$}

- Drafting different prevention plans and programs concerning minors criminality phenomenon, especially in those neighbors and schools where there are more problems;

- The enforcement of existing legislation etc.

It is evident that implementation of these and other measures of this nature in Kosovo did not have a good performance during these years of transition. In this regard, is estimated that undertaking these and other preventive measures is the best guarantee of long-term fighting juvenile criminality.

\subsection{Repressive Measures}

Repression is another form of social reaction against criminality. That job is entrusted mainly to bodies and specialized organizations, in the first place of those state organizations (police, prosecution, courts, execution sentences bodies etc.). Repressive measures are foreseen by the law and as such intended to protect life and other human values and society from criminal acts. (Note 28). Repressive measures used for combating juvenile criminality may be of two types: the detecting and prosecuting policy of juvenile perpetrators and application policy of criminal sanctions against this category of perpetrators.

\subsubsection{The Detecting and Prosecuting Policy of Juvenile Criminal Offences Perpetrators}

The detecting and solving juvenile criminal offences and their perpetrators it has a special importance in combating this form of criminality. The detection of minors criminal offences it has a special importance also in decreasing their dark figure of crime. (Note 29). It is considered that until now in Kosovo is not done enough in combating juvenile criminality. The reasons for this are numerous and varied. "They first of all have to do with the inadequate treatment done by competent bodies to juvenile perpetrators of criminal offences.

Except the detection and identification of juvenile criminality the key issue in order for justice to triumph against crime is the detection and bringing to justice their perpetrators. The results of this paper prove that in this regard, despite the achieved results, in police and prosecution job are manifested certain stagnations. These stagnations have to deal mostly with no detection of many committed crimes by juveniles and with non-processing $30 \%$ of detected cases of these crimes (the application of alternative proceedings and termination of investigation).

After the detection of juvenile perpetrators of criminal offences, in order for the fight against this form of crime to achieve the desirable effects is necessary that their perpetrators must be prosecuted and arrested. The results of this paper prove that during the period of time 2009-2014 for commission of criminal offences were arrested 1459 persons, of whom 1312 were released after the expiration of deadline of 48 hours after their arrest (Note 30). Also, according to State Prosecution data for commission of different criminal offences against minors during the conducting period of this research (2009-2013) were filed 125238 indictments (Note 31). 
In order to achieve a more successful fight against juvenile criminality it is required an advanced engagement of authorized bodies for combating crime (police, state prosecution, courts etc.) as well as cooperation and professional teamwork in matters regarding the fight of this criminality.

7.2.2 Application Policy of Criminal Sanctions against Juvenile Perpetrators of Criminal Offences

Successfully combating juvenile criminality can contribute significantly, by applying adequate criminal policy in the field of criminal sanctions application. "In this regard, the main role belongs to punishments imposed against criminal offences perpetrators during criminal proceedings" (Note 32). In this case, is deemed in adequate punishments, such that are in accordance with social dangerousness degree of criminal offence and effective re-socialization of perpetrator.

The modest results of this paper prove that during the period of time 2009-2013 courts imposed punishments by imprisonment to 238 persons, of which only 32 by punishment over 5 years of imprisonment, by institutional measures have punished 717 persons, by diversity measures 1413 persons, disciplinary measures 846 persons, measures of intensive supervision 913 persons, community service work 463 persons and other measures 648 persons. It is worth it to emphasize the fact during this period of time has come to the statutory limitation of 357 cases for which indictment has been filed (Note 33).

These data prove that Koso vo courts concerning juvenile perpetrators of criminal offences have applied relatively soft criminal policy and in their job is noticed a considerable work negligence. Bearing in mind the relatively high presence degree of criminal offences committed by minors I consider that courts are supposed to apply a little more aggravate criminal policies.

\section{Conclusion}

Juvenile criminality represents a very social complicated phenomenon which occurs since the most ancient times of human society development. This form of criminality, for many reasons continues to attract a big interest in scientific and state circles at all levels. As such this causes numerous socio-economic, psychological and other individual and social consequences.

In the appearance of juvenile criminality influence numerous factors, general and special. The result of this scientific paper come to the conclusion that this type of criminality significantly has been determined by socio-economic, political and also other circumstances dominating social life in a particular place.

During the progress study of Kosovo juvenile criminality for the period of time 2009-2013 it was concluded that this form of criminality has achieved a relatively high presence with great social consequences for individuals, families and country in general. 
In this research has been concluded that juvenile delinquents basically derive from degraded and problematic families, deficient and those with many members which for different causes and circumstances were not able to take care of them as they should have.

Modest results of this scientific paper prove that juvenile perpetrators of criminal offences are characterized by low educational and cultural level, and they are mostly of masculine gender and significantly are from families with poor economic situation.

A special importance in juvenile prevention criminality has the consolidation of democracy and the rule of law. In this regard, it has been concluded that in order to achieve this goal responsible state bodies must increase their work efficiency.

Punitive policy against perpetrators of criminal offences, in general, is considered to be soft, which has been estimated to be reasonable based on their new age and other circumstances conditioning such age.

\section{References}

Criminal Code of the Republic of Kosovo entered into force on January 1, 2013. April 20, 2012),

Elezi, I. (1999). Criminal Law (The Special Part I). Tirana.

Hajdari, A. (2003). Corruption criminal offences nature with a special focus in Kosovo. Prishtina.

Hajdari, A. (2010). Juvenile Justice System. Commentary. Prishtina.

Hajdari, A. (2013). Criminal Law Procedure (The Special Part). Prishtina.

Hajdari, A.(2004). Juvenile Criminality in Kosovo 2001 - 2003. Prishtina.

Halili, R. (2000). Criminology. Prishtina.

Jurisprudence statistics for adults convicted during the period of time 2009-2013 of Kosovo Statistical Agency http://ask.rks-gov.net/ and Kosovo Judicial Council reports for adults convicted during the period of time 2009 - 2013 http://www.kgjk-ks.org/

Jurisprudence Statistics for juveniles convicted during the period of time 2009 - 2013 of Kosovo Statistical Agency http://ask.rks-gov.net/ and Kosovo Judicial Council reports for juveniles convicted during the period of time 2009 - $2013 \mathrm{http} / /$ www.kgjk-ks.org/

Juvenile Justice Code entered intoforce on July 23, 2010.

Kosovo Police statistical data over filed criminal reports for the period of time. 2009 2013.

Latifi, V. (1997). Some observations regarding juvenile and children deliquent behaviours. The Law (No. 1). Prishtina.

Milutinoviq, M. (1987). Criminal Policy. Prishtina.

Salihu, I. (2003). Criminal Law (General Part). Prishtina. 
Salihu, I. (2005). Juvenile Criminal Law. Prishtina.

Salihu, I., Zhitija, I., \& Hasani, F. (2014). The Criminal Code of Kosovo, Commentary. Prishtina.

Siegel, I. (1996). Droite de Criminologie. Paris.

State Prosecutor statistical data over filed indictments for the period of time. 2009 - 2013.

\section{Notes}

Note 1. Hajdari A. Juvenile Criminality in Kosovo 2001 - 2003, Prishtina, 2004, p. 25.

Note 2. Ibid, p. 26.

Note 3. Ibid, p. 26.

Note 4. Latifi V. Some observations regarding juvenile and children deliquent behaviours, The Law, No.1, Prishtina, 1997, p. 31.

Note 5. The Criminal Code of the Republic of Kosovo entered into force on January 1, 2013 (Code No.04/L-82, April 20, 2012),

Note 6. Juvenile Justice Code entered into force on July 23, 2010 (Code No.03/L-193).

Note 7. This Code contains 162 articles.

Note 8. Hajdari A. Juvenile Justice System, Commentary, Prishtina, 2010, p. 48-49.

Note 9. Salihu I. Juvenile Criminal Law, Prishtina, 2005, p. 22-23.

Note 10. Hajdari A. Criminal Law Procedure, The Special Part, Prishtina, 2013, p. 125 126.

Note 11. Hajdari A. Juvenile Justice,..., p. $217-218$.

Note 12. Halili R. Criminology, Prishtina, 2000, p. 208.

Note 13. Salihu I. Criminal Law, The General Part, Prishtina, 2003, p. 243.

Note 14. Siegel I, Droite de Criminologie, Paris, 1996, p. 204.

Note 15. Jurisprudence Statistics for juveniles convicted during the period of time 2009 2013 of Kosovo Statistical Agency http://ask.rks-gov.net/ and Kosovo Judicial Council reports for juveniles convicted during the period of time 2009 - $2013 \mathrm{http}: / / w w w . k g j k-$ ks.org/.

Note 16. Ibid.

Note 17. Ibid.

Note 18. Mitrovica Basic Court during the research period 2009-2013 had conducted the judicial activities in very difficult conditions. Data over convicted juveniles by this court 
were not available at Kosovo Judicial Council data. They were provided from evidences criminal minors cases of Mitrovica Basic Court operating in Vushtrri.

Note 19. Jurisprudence Statistics for juveniles convicted during the period of time $2009-$ 2013 of Kosovo Statistical Agency http://ask.rks-gov.net/ and Kosovo Judicial Council reports for juveniles convicted during the period of time 2009 - 2013 http://www.kgjkks.org/.

Note 20. According to the Kosovo Judicial Council data, Kosovo courts at the end of first half of 2014 had 463301 unresolved court cases, almost half of them with criminal nature. For this see: Half year report of courts work in 2014 published at http://www.kgjk-ks.org/.

Note 21. Jurisprudence Statistics for juveniles convicted during the period of time 2009 2014 of Kosovo Statistical Agency http://ask.rks-gov.net/ and Kosovo Judicial Council reports for juveniles convicted during the period of time 2009 - 2013 http://www.kgjkks.org/.

Note 22. Compare: Elezi I. Criminal Law, The Special Part I, Tirana, 1999, pg 64, and Salihu I, Zhitija H, and Hasani F, Criminal Code of Kosovo, Commentary, Prishtina, 2014, p. 678.

Note 23. Jurisprudence Statistics for juveniles convicted during the period of time 2009 2013 of Kosovo Statistical Agency http://ask.rks-gov.net/ and Kosovo Judicial Council reports for juveniles convicted during the period of time 2009 - 2013 http://www.kgjkks.org/.

Note 24. Note 24. Halili R. Criminology,.., p. 77.

Note 25. Jurisprudence Statistics for juveniles convicted during the period of time 2009 2013 of Kosovo Statistical Agency http://ask.rks-gov.net/ and Kosovo Judicial Council reports for juveniles convicted during the period of time 2009 - 2013 http://www.kgjkks.org/.

Note 26. Ibid.

Note 27. Milutinoviq M. Criminal Policy, Prishtina, 1987, p. 388.

Note 28. Compare: Hajdari A. Corruption Criminal offences nature with a special focus in Kosovo Prishtina, 2003, p. 124-125.

Note 29. Family for many different reasons hesitate to report numerous criminal offences cases committed by their children, especially when others have no information about it.

Note 30. See: Kosovo Police statistical data over filed criminal reports for the period of time $2008-2013$,

Note 31. See: State Prosecutor statistical data over filed indictments for the period of time $2009-2013$,

Note 32. Milutinoviq M. Criminal Policy,..., pg. 258. 
Note 33. See: Statistical reports (periodical and annual) of Kosovo Judicial Council over the manner of resolving judicial cases for the period of time 2009-2013. 